Indonesian Journal of Islamic Communication, Vol. 1, No. 2, Desember 2018: 1-21

\title{
KRITIK FILSAFAT ILMU TERHADAP KOMUNIKASI PENGETAHUAN MODERN
}

\author{
Nova Saha Fasadena \\ Program Studi Komunikasi dan Penyiaran Islam \\ Institut Agama Islam Negeri Jember
}

Diunggah 29 Oktober / Direvisi 21 November / Diterima 28 Desember 2018

\begin{abstract}
Abstrac: We live in a modern world full of problems, not least the world of communication. The philosophy of science is present as one of solution to overcome this problem. In the era of information technology, there are many social media that fill every society in the digital world. In this case technological advances will bring effects that be able to affect people's lives, starting from the good and bad effects that will come. This research is expected to make the general public social users, especially academics, to be more serious in processing information and sorting information that can be trusted. Using descriptive analysis methods with the theories of communication to identify the modern communication problem such as information on social media, so this method is one of the ways that can be used to identify and eliminate information from news media that is not true. The announcement of the results of this research is expected to be useful for media users both from the cloud community, the academic environment, and the government.
\end{abstract}

Keywords; philosophy, science, communication, modern knowledge

Korespondensi: Nova Saha Fasadena

Umbulrejo-Umbulsari-Jember 68166

novahdt@gmail.com 


\section{A. PENDAHULUAN}

Salah satu ciri yang membedakan Agama Islam dengan yang lainnya adalah penekanannya terhadap masalah ilmu (sains). Al-Quran dan As-Sunnah mengajak kaum muslim untuk mencari dan mendapatkan ilmu dan kearifan, serta menempatkan orang-orang yang beriman dan berpengetahuan pada derajat yang tinggi.

Dengan semangat keilmuan, pada masa kini orang berlomba-lomba menggali teknologi dan informasi agar dapat mencapai kemudahan, kekayaan, dan kebahagiaan yang sebanyak-banyaknya. Kemajuan industri dan dunia komunikasi saat ini telah menghasilkan alat-alat yang memudahkan hidup, memberikan kesenangan dalam hidup, sehingga kebutuhan-kebutuhan jasmani tidak sukar lagi untuk memenuhinya.

Dunia komunikasi saat ini, mengakibatkan masyarakat modern telah berhasil mengembangkan ilmu pengetahuan dan teknologi canggih untuk mengatasi berbagai masalah hidupnya. Jika zaman dahulu orang mengetahui kabar berita dari mulut ke mulut, namun dengan komunikasi modern saat ini, orang hanya perlu membuka ponsel pintar dan menggali informasi yang dibutuhkan melalui internet dengan efektif dan efisien. Teknologi modern juga memudahkan manusia untuk bebas mengemukakan pendapat dan menyebarluaskan informasi hanya dalam hitungan detik. Menurut data kominfo, secara keseluruhan, jumlah pengguna internet di seluruh dunia diproyeksikan bakal mencapai 3 miliar orang pada 2015. Tiga tahun setelahnya, pada 2018, diperkirakan sebanyak 3,6 miliar manusia di bumi bakal mengakses internet setidaknya sekali tiap satu bulan. Pada 2017, eMarketer memperkirakan pengguna internet Indonesia akan mencapai 112 juta orang, mengalahkan Jepang di peringkat ke-5 yang pertumbuhan jumlah pengguna internetnya lebih lamban. ${ }^{1}$ Bahkan menurut laporan terbaru dari Asosiasi Penyelenggara Jasa Internet Indonesia ( APJII). Dari jumlah total populasi penduduk Indonesia saat ini mencapai 262 juta orang, lebih dari 50 persen atau sekitar 143 juta orang telah terhubung jaringan internet sepanjang 2017. ${ }^{2}$ Berdasarkan data tersebut bisa kita simpulkan bahwa komunikasi modern telah meningkat pesat dari masa ke masa. Dengan pertumbuhan jumlah penduduk dan perkembangan modernisasi,

${ }^{1}$ https://kominfo.go.id/index.php/content/detail/4286/Pengguna+Internet+Indonesia+Nomor+Enam+D unia/0/sorotan_media diunduh tanggal 27 Oktober 2018.

2 https://apjii.or.id/survei2017 diunduh tanggal 27 Oktober 2018 
bukan tidak mungkin hampir semua orang akan mengakses informasi melalui komunikasi modern ini.

Namun pada sisi lain, kemajuan ilmu pengetahuan dan teknologi tersebut tidak mampu menumbuhkan moralitas (akhlak) yang mulia. Dunia modern saat ini, termasuk di Indonesia ditandai oleh gejala kemerosotan akhlak yang benar-benar berada pada taraf yang mengkhawatirkan. Kejujuran, kebenaran, keadilan, tolong menolong dan kasih sayang sudah tertutup oleh penyelewengan, penipuan, banyaknya berita hoax, dan saling merugikan. Perilaku yang terjadi saat ini adalah bekerja sama untuk kepentingan kelompoknya dan secara berkelompok melakukan penipuan, pencurian, penindasan. Kominfo sendiri mengaku sudah memblokir setidaknya 773.097 situs negatif melalui Trust Postif. Sebagian besar yang dblokir merupakan situs pornogafi. ${ }^{3}$ Dari data yang diterima CNNindonesia.com, sekitar 90 persen atau 767.888 situs pornografi sudah diblokir oleh Kominfo. Sementara konten perjudian, termasuk situs kedua paling banyak diblokir dengan jumlah 3.755. Data itu sendiri menyebut, jumlah situs radikalisme yang diblokir sebanyak 87 sementara konten SARA tak lebih dari 51 situs dari kurun waktu Januari 2016 sampai pertengahan Desember. ${ }^{4}$ Namun dengan banyaknya situs yang terblokir tersebut, faktanya masih banyak oknum yang terus menerus menyebarkan informasi yang tidak bertanggung jawab meski pemerintah sudah mencoba menanggulanginya sehingga perlu ada solusi lain untuk memecahkan permasalahan tersebut, salah satunya adalah melalui filsafat.

Filsafat (khususnya filsafat ilmu) berusaha mengembalikan ruh dan tujuan luhur ilmu agar ilmu tidak menjadi bomerang bagi kehidupan umat manusia. Di samping itu, salah satu tujuan filsafat ilmu adalah untuk mempertegas bahwa ilmu dan teknologi adalah instrumen dalam berkomunikasi bukan tujuan. Dalam konteks yang demikian diperlukan suatu pandangan yang komprehensif tentang ilmu dan nilai-nilai yang berkembang di masyarakat. Krisis dan kemerosotan moral yang terjadi pada masyarakat modern ditanggapi oleh Herman Soewardi adalah sebagai berikut :

\footnotetext{
3https://www.kominfo.go.id/content/detail/8629/asal-mula-situs-hoax-berkembang-diindonesia/0/sorotan_media diunduh tanggal 27 Oktober 2018

$4 \quad$ http://www.cnnindonesia.com/teknologi/20161230125808-185-183096/asal-mula-situs-hoaxberkembang-di-indonesia/ diunduh tanggal 27 Oktober 2018
} 
“...Filosof dan ilmuan Barat mulai mengakui bahwa arah yang keliru. Arah yang ditempuh telah memberikan kenikmatan, namun kenikmatan yang diiringi dengan kehancuran. ..Kehancuran itu dapat berubah lebih besar daripada kenikmatannya. Mereka mengetahui ilmu yang selama ini diyakini kebenarannya adalah salah, tetapi tidak tahu menunjukkan mana yang benarnya. Akhirnya upaya mereka menjadi stagnan tidak tahu apa yang harus dilakukan. Mereka sangat percaya kepada empirisme dan positivisme, Namun tetap tidak mampu menunjukkan kebenaran inilah yang disebut dengan skeptisisme. Hal ini karena yang benar itu satu, sedangkan yang tidak benar itu banyaknya tidak terhingga. Untuk sampai kepada yang benar, maka harus mengetahuikesalahan dari ilmu itu terlebih dahulu. Bersyukurlah manusia kepada Tuhan YME, yang menciptakan itu semua. Ia telah memberitahukan kepada manusia melalui Nabi Muhammad SAW, mana yang benar dan mana yang salah. Kebenaran adalah perintah-Nya untuk dijalani oleh umat manusia. Kesalahan adalah merupakan larangan-Nya untuk dihindari oleh umat manusia. Dalam masyarakat beragama (Islam), ilmu adalah bagian yang tak terpisahkan dari nilai-nilai ketuhanan karena sumber ilmu yang hakiki adalah dari Tuhan. Cara untuk mengalihkan ilmu yang keliru itu maka manusia tidak hanya mengandalkan diri pada akal saja, akan tetapi meletakkan akal di bawah ketentuan-ketentuan dari Allah. Dengan kata lain suatu ilmu harus dipandu dengan normatif dari Allah SWT atau naqliah memandu aqliah". 5

Penting kita ketahui bahwa ikatan agama yang terlalu kaku dan terstruktur kadang kala dapat menghambat perkembangan ilmu. Karena itu, perlu kejelian dan kecerdasan memperhatikan sisi kebebasan dalam ilmu dan sistem nilai dalam agama agar keduanya tidak saling bertolak belakang. Di sinilah perlu rumusan yang jelas tentang ilmu secara filosofis dan akademik serta agama agar ilmu dan teknologi tidak menjadi bagian yang lepas dari nilai-nilai agama dan kemanusiaan serta lingkungan khususnya dalam dunia komunikasi.

Berdasarkan uraian yang telah dipaparkan di atas, tulisan ini mengkaji antara filsafat ilmu dan komunikasi pengetahuan modern, Oleh karena itu permasalahan dibatasi adalah sebagai berikut: Bagaimanakah filsafat ilmu dalam komunikasi pengetahuan modern yang berlandaskan Islam?

\footnotetext{
${ }^{5}$ Herman Soewardi, Roda berputar, Dunia Bergulir: Kognisi Baru tentang Timbul Tenggelamnya Sivilisasi, Bakti Mandiri, Bandung, 2004, 9-19.
} 


\section{B. PEMBAHASAN}

\section{Filsafat Ilmu Dalam Komunikasi Pengetahuan Modern berlandaskan Islam}

\section{a. Ilmu pengetahuan dalam konsep Islam}

Islam sebagai agama yang sangat menghormati ilmu pengetahuan, tidak diragukan lagi. Banyak argumen yang dapat dirujuk, di samping ada ayat-ayat alQur`an dan hadits Nabi SAW. yang mengangkat derajat orang berilmu, juga di dalam al-Qur`an mengandung banyak rasionalisasi, bahkan menempati bagian terbesar. Hal ini diakui Meksim Rodorson (seorang penulis Marxis) ketika menelaah QS. AlBaqarah: 164:

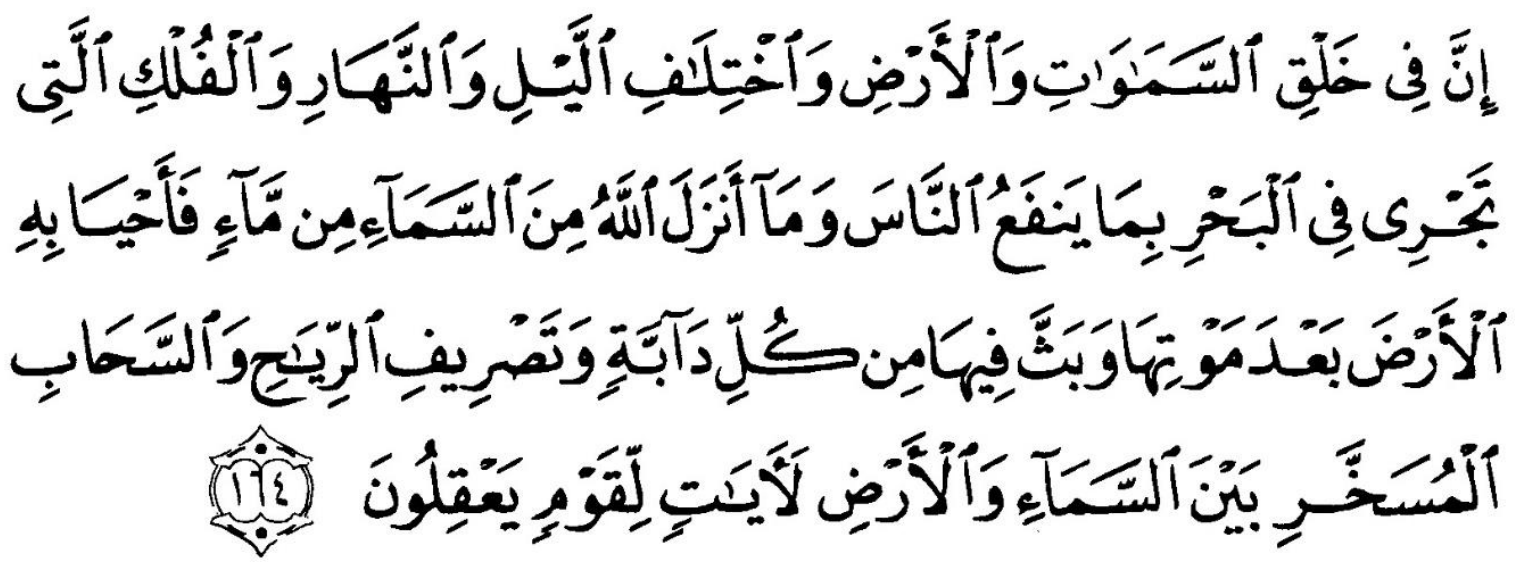

Artinya : "Sesungguhnya dalam penciptaan langit dan bumi, silih bergantinya malam dan siang, bahtera yang berlayar di laut membawa apa yang berguna bagi manusia, dan apa yang Allah turunkan dari langit berupa air, lalu dengan air itu Dia hidupkan bumi sesudah mati (kering)-nya dan Dia sebarkan di bumi itu segala jenis hewan, dan pengisaran angin dan awan yang dikendalikan antara langit dan bumi; sungguh (terdapat) tanda-tanda (keesaan dan kebesaran Allah) bagi kaum yang memikirkan."6

Menurut Rodorson dalam al-Qur'an kata 'aqala dari ayat liqaumi ya'qiluun (mengandung pengertian menghubungkan sebagian pikiran dengan sebagian yang lain dengan mengajukan bukti-bukti yang nyata sebagai argumentasi yang harus dipahami secara rasional) disebut berulang kali, tidak kurang dari lima puluh kali dan sebanyak tiga belas kali berupa bentuk pertanyaan sebagai protes yang mengarah pada kajian ilmiyah, seperti "Apakah kamu tidak berakal?".

Maka dapat dikatakan bahwa ilmu itu membutuhkan pembuktian (dalil, hujjah atau argumen) sebagai hasil dari sebuah pencarian, dan al-Qur`an mengisyaratkan mengenai hal ini. Setiap kali Allah menerangkan fakta-fakta

${ }^{6} \mathrm{Al}-\mathrm{Quran}$ dan Terjemahan, Departemen Agama 
penciptaan, lalu diiringi dengan pernyataan, misalnya dalam QS. Ali Imran: 190191:
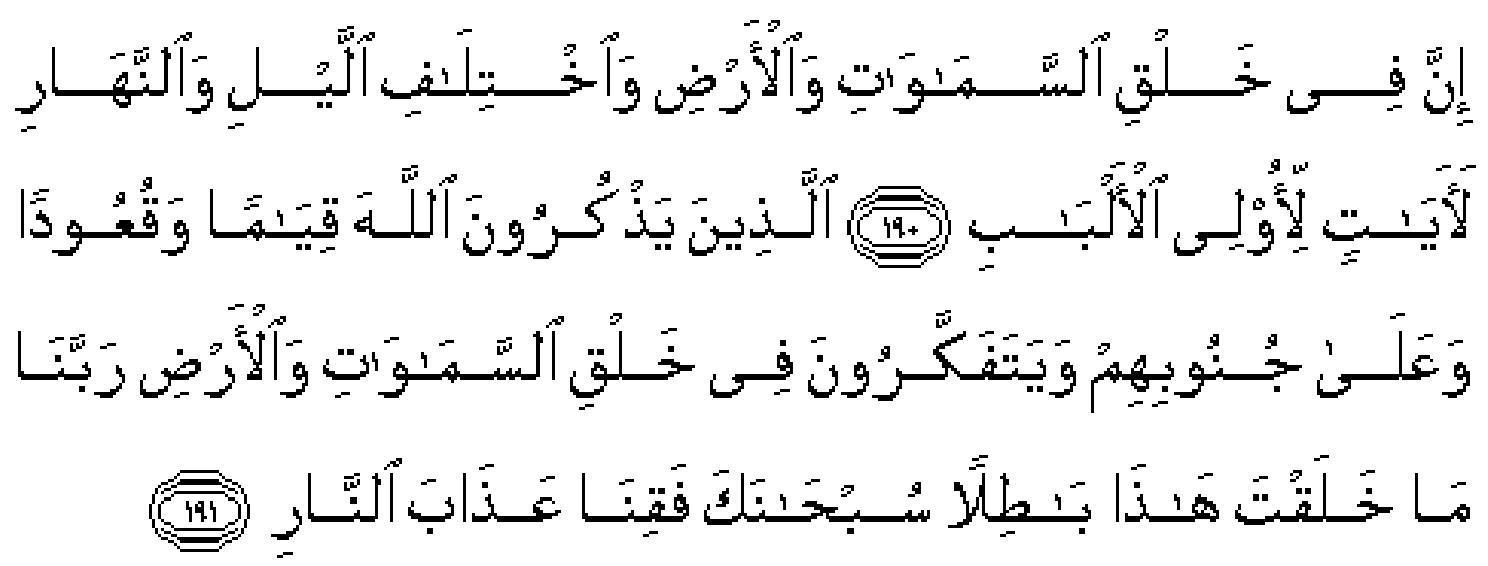

Artinya: Sesungguhnya dalam penciptaan langit dan bumi, dan silih bergantinya malam dan siang terdapat tanda-tanda bagi orang-orang yang berakal, (yaitu) orang-orang yang mengingat Allah sambil berdiri atau duduk atau dalam keadan berbaring dan mereka memikirkan tentang penciptaan langit dan bumi (seraya berkata): "Ya Tuhan kami, tiadalah Engkau menciptakan Ini dengan sia-sia, Maha Suci Engkau, Maka peliharalah kami dari siksa neraka7.

Karena itu, ada beberapa definisi al-'ilmu yang disodorkan para ulama sebagaimana dikemukakan Syarief 'Ali bin Muhammad al-Jarjani, yaitu: "keyakinan yang pasti sesuai dengan kenyataan”, "sampainya gambaran sesuatu terhadap akal”, "hilangnya keraguan setelah diketahui", "hilangnya kebodohan”, "merasa cukup setelah tahu".

Dikatakan pula "sebagai sifat yang mendalam yang dapat mengetahui perkara yang universal dan farsial" atau "sampainya jiwa kepada sesuatu makna yang diketahui". Adapula yang memberikan definisi dengan "ilmu adalah istilah untuk menyebutkan terjadinya kesinambungan yang khusus antara subjek yang berpikir dan objek yang dipikirkan”. Juga (pengertian yang lebih ringkas) "mengetahui sifat persifat".

Disebut Ilmu al-Yaqin, adalah pengetahuan yang berdasarkan dalil dengan gambaran berupa perkara yang meyakinkan ${ }^{8}$. Karena itu cara pandang seseorang terhadap 'sesuatu' itu, merupakan pandangan hidupnya.

Lahirnya ilmu dalam Islam didahului oleh adanya tradisi intelektual yang tidak lepas dari kandungan al-Qur’an dan penjelasannya dari Nabi. Jadi, jika

\footnotetext{
${ }^{7}$ Al-Quran dan Terjemahan, Departemen Agama

${ }^{8} \mathrm{Http}: / /$ pusdiklat-dewandakwah.com/Akses pada tanggal 20 Oktober 2018
} 
kelahiran ilmu dalam Islam dibagi secara periodik, menurut Hamid Fahmi Zarkasy urutannya sebagai berikut: (1) Turunnya wahyu dan lahirnya pandangan hidup Islam, (2) Adanya struktur ilmu pengetahuan dalam al-Qur`an dan al-Hadits, (3) Lahirnya tradisi keilmuan Islam, dan (4) Lahirnya disiplin ilmu-ilmu Islam9.

Pencarian ilmu merupakan konsep penting dan merupakan hal pokok dalam ajaran Islam. Hal ini dapat diilustrasikan dalam Hadist, "Mencari ilmu itu wajib bagi setiap muslim" melahirkan berbagai pembahasan. ${ }^{10}$ Selanjutnya Al-Ghazali membahas ilmu yang termasuk wajib kifayah. Artinya, sesuatu yang wajib atas keseluruhan masyarakat, selama kewajiban untuk memenuhi kebutuhan sosial itu masih ada. Namun setelah kewajiban itu dilaksanakan oleh sejumah individu, maka yang lainnya terbebas dari kewajiban itu. ${ }^{11}$

Al-Gazhali mengklasifikasikan "Ilmu" ke dalam ilmu agama dan ilmu nonagama. ${ }^{12}$ Ilmu agama adalah ilmu yang diajarkan melalui ajaran-ajaran nabi dan wahyu. Sedangkan di luar itu disebut dengan ilmu non-agama. Ilmu agama dibagi dalam ilmu terpuji (Mahmud) dan ilmu tercela (madzmum). Ilmu agama yang terpuji dibagi 4 (empat) kelompok yaitu , Ushul (dasar-dasar), Furu' (masalah sekunder atau cabang), Studi-studi pengantar, Studi-studi pelengkap. Ilmu Agama yang tercela yaitu, tampaknya diarahkan kepada syariah akan tetapi sebenarnya menyimpang dari ajaran-ajaran agama. Ilmu non-agama dibagi ke dalam 3 (tiga) kategori yaitu, ilmu non-agama yang terpuji (mahmud) yaitu ilmu-ilmu yang penting dalam kehidupan sehari-hari, ilmu non-agama yang dibolehkan (mubah), contohnya, ilmu sejarah dan ilmu non-agama tercela (madzmum), misalnya ilmu sihir.

Berdasarkan uraian tersebut di atas dapat ditarik kesimpulan sebagai berikut yaitu:

1) Allah sangat mendorong dikembangkannya ilmu pengetahuan melalui firmanfirman-Nya. Hal ini terlihat dari banyaknya ayat al Qur'an yang menyuruh manusia agar menggunakan akal pikiran dan segenap potensi yang dimilikinya untuk memperhatikan segala ciptaan Allah SWT.

\footnotetext{
9 Hamid Fahmi Zarkasy, Seminar Pandangan Hidup dan Epistemologi Islam: Studi Kasus Sains Islam, "Pandangan Hidup sebagai Asas Epistemologi Islam", 2006. 9

${ }^{10}$ Mahdi Ghulsyani, (diterjemahkan oleh Agus Effendi), Filsafat-Sains Menurut Al-Quran, (Bandung; Mizan, 1994), 40.

${ }_{11}$ Ibid,. 41.

${ }^{12}$ Ibid,. 41
} 
2) Dorongan al Qur'an terhadap pengembangan ilmu pengetahuan tersebut terlihat pula dari banyaknya ayat al Qur'an yang berkaitan dengan ilmu pengetahuan, pujian dan kedudukan yang tinggi bagi orang-orang yang berilmu serta pahala bagi yang menuntut ilmu.

3) Bahwa temuan manusia dalam bidang ilmu pengetahuan patut dihargai. Namun tidak sepatutnya membawa dirinya menjadi sombong dibandingkan dengan kebenaran al Qur'an. Temuan manusia tersebut terbatas dan tidak selamanya benar, sedangkan al Qur'an bersifat mutlak dan berlaku sepanjang zaman.

4) Al-Qur'an adalah kitab yang berisi petunjuk termasuk petunjuk dalam pengembangan ilmu pengetahuan, yaitu agar ilmu pengetahuan dikembangkan untuk tujuan peningkatan ibadah, akidah, dan akhlak yang mulia.

5) Kemajuan yang dicapai oleh manusia dalam bidang ilmu pengetahuan harus ditujukan untuk mencapai kebahagiaan hidup di dunia dan di akhirat. Hal ini akan terjadi manakala tujuan dari pengembangan ilmu pengetahuan tersebut tidak dilepaskan dari dasar peningkatan ibadah, akidah, dan akhlak tersebut.

\section{b. Pengertian filsafat Ilmu}

Ahmad Tafsir, menyatakan pengertian filsafat berhubungan erat dengan Bahasa Yunani, (Griek) yaitu philosophia. Namun demikian pendapat lainnya ada juga yang mengatakan filsafat berasal dari bahasa Arab "falsafah" atau "filsafah". ${ }^{13}$ Kata Philosophia merupakan kata majemuk yang memiliki arti, "Philo" yaitu cinta dalam arti yang luas, yaitu ingin dan karena itu berusaha mencapai yang diinginkan itu. Kata Sophia berarti kebijaksanaan, pandai, pengertian yang mendalam. Dengan kata lain Filsafat diartikan pandai, cinta pada kebijakan. ${ }^{14}$ The Liang Gie mendefinisikan filsafat ilmu, adalah segenap pemikiran reflektif terhadap persoalan-persoalan mengenai segala hal yang menyangkut baik landasan ilmu maupun hubungan ilmu dengan segala segi dari kehidupan manusia. ${ }^{15}$

\footnotetext{
${ }^{13}$ Harun Nasution dalam Amsal Bakhtiar, Filsafat ilmu, RadjaGrafindo, Jakarta, 2004. Harun Nasution menyatakan istilah filsafat berasal dari Bahasa Arab, karena orang Arab terlebih dahulu datang dan mempengaruhi bahasa Indonesia daripada orang dan Bahasa Inggris, hlm. 4-5. Lihat juga Sutardjo A. Wiramihardja, Pengantar Filsafat: Sistematika dan Sejarah Filsafat Logika dan Filsafat ilmu (Epistemologi) Metafisika dan Filsafat Manusia Aksiologi, (Bandung; Refika Aditama, 2009), 13.

${ }^{14}$ Ahmad Tafsir, Filsafat Umum: Akal dan Hati Sejak Thales sampai Capra, (Bandung; Rosda, 2007),9. Bandingkan dengan Ahmad Hanafi, Pengantar Filsafat Islam , (Jakarta; Bulan Bintang, 1990),3.

${ }^{15}$ The Liang Gie, Pengantar Filsafat Ilmu, (Yogyakarta; Liberty, 2007), 27-29.
} 
Filsafat tidak lepas dari permasalahan tidak terkecuali filsafat ilmu pengetahuan dan semua cabang filsafat lainnya. Kesemuanya memilki problematika yang nyaris sama. Harold, H. Titus dan beberapa filsof dewasa ini, dalam menjelaskan situasi problematis menyatakan bahwa "filsafat sekarang telah mencapai kekuatan besar tetapi tanpa kebijaksanaan,"16 kita hidup dalam suatu periode yang mirip dengan tahap-tahap terakhir dari kebudayaan Greeko-romawi, Renaissance, reformasi, dan revolusi industri dimana terjadi perubahan dalam cara manusia berpikir, dalam nilai dan praktik, atau terjadi perubahan-perubahan yang menyentuh kehidupan manusia dan masyarakat. Sekarang manusia memilki kemampuan yang sangat besar untuk menguasai alam dan ruang angkasa. Manusia melakukan loncatan-loncatan raksasa dalam bidang sains, teknologi pertanian, kedokteran, ilmu-ilmu sosial, dan pendidikan. Sekarang ini kita menyaksikan kemajuan pengetahuan manusia; manusia hidup lebih panjang, berpergian lebih cepat, memiliki kenikmatan (comfort) dan alat-alat yang menghemat tenaga, serta menghasilkan bahan yang lebih banyak dalam waktu yang lebih singkat. Zaman serba mesin sekarang ini jelas akan menghilangkan keletihan jasmani, menambahkan produksidan mengurangi jam kerja. Kemampuan untuk menguasai sumber-sumber energi atom, matahari, ombak laut, serta angin, bukanlah merupakan khayali, tetapi benar-benar dalam kehidupan kita. dan mengurangi jam kerja. Kemampuan untuk menguasai sumber-sumber energi atom, matahari, ombak laut, serta angin, bukanlah merupakan khayali, tetapi benar-benar dalam kehidupan kita.

Roger Geraudy mengemukakan analisisnya bahwa "perkembangan" filsafat dan peradaban modern saat ini mendorong manusia kepada hidup tanpa tujuan dan membawanya kepada kematian. Hal ini merupakan akibat dari perkembangan filsafat barat modern yang salah arah, yang berpegangan pada:

a. Konsep yang keliru tantang alam, alam dianggap milik manusia dan ia berhak memanfaatkanya, termasuk merusaknya, sehingga mamnusia tidak memandang, kecuali sebagai reservoir kekayaan alam dan tempat pembuangan sampah dan polusi. Dengan cara ini, dengan habisnya sumber-sumber alam dengan polusi, manusia telah menghancurkan lingkungannya yang vital dan

16Dalam Muhaimin, Studi Islam dalam ragam dimensi dan pendekatan,(Jakarta; prenadamedia group, 2005), 6. 
menjadi pembantu yang tidak sadar bagi peraturan entrophy, yakni kaidah tentang berkekurangan energi dan bertambahnya kekacaauan

b. Konsep yang tidak mengenal belas kasihan tentang hubungan manusia, didasarkan pada individualisme tanpa kendali dan hanya menghasilkan masyarakat persaingan pasar, konfrontasi, kekerasan, dimana beberapa kesatuan ekonomi atau politik yang ketat dan sangat kuat memperbudak atau memangsa mereka yang lebih lemah.

c. Konsep yang menyebabkan rasa putus asa terhadap masa depan yang hanya akan merupakan kepanjangan dan penambahan kuantitatif dari keadaan sekarang, tanpa tujuan kemanusian, dan tanpa hubungan dengan tuhan, serta tanpa sesuatu yang transeden yang mengatasi cakrawala ini, untuk memberikan arti kepada hidup umat manusia dan mengelakkan mereka dari jalan yang menuju kematian. ${ }^{17}$

Demikian situasi problematis yang ditimbulkan oleh pengetahuan dan filsafat modern dewasa ini. Situasi semacam ini bukan hanya menimpa dan merupakan tantangan bagi bangsa bangsa modern yang menjadi penyebab timbulnya, tetapi juga menimpa dan merupakan tantangan bagi seluruh umat manusia di seluruh dunia, termasuk didalamnnya umat Islam, sehingga muncul wacana untuk mencoba memecahkan situasi problematis tersebut melalui filsafat ilmu.

Berdasarkan uraian di atas maka dipahami "filsafat ilmu" merupakan bagian dari filsafat pengetahuan yang secara spesifik mengkaji hakekat ilmu. Ilmu merupakan cabang pengetahuan yang mempunyai ciri-ciri tertentu, meskipun secara metodologis ilmu tidak membedakan antara ilmu alam dengan ilmu-ilmu sosial, namun karena permasalahan-permasalahan teknis yang bersifat khas, maka filsafat ilmu dibagi menjadi filsafat ilmu-ilmu alam dan filsafat ilmu-ilmu sosial. Pembagian ini lebih merupakan pembatasan masing-masing bidang yang ditelaah, yakni ilmu-ilmu alam dan ilmu-ilmu sosial, dan tidak mencirikan cabang filsafat yang otonom. Ilmu memang berbeda dengan pengetahuan-pengetahuan secara filsafat, namun tidak terdapat perbedaan yang prinsipil antara ilmu-ilmu alam dan ilmu-ilmu sosial, di mana keduanya mempunyai ciri-ciri yang sama.

\section{Filsafat Ilmu dalam Komunikasi Pengetahuan Modern}

\footnotetext{
${ }^{17}$ Roger Geraudy, Janji-Janji Islam, terj. H.M.Rasyidi, (Jakarta:Bulan Bintang, 1982), 29.
} 
Komunikasi adalah suatu proses simbolik. Salah satu kelebihan manusia dari makhluk lain (hewan) adalah ia diberi kemampuan untuk berfikir sehingga manusia mempunyai kemampuan untuk menggunakan lambang. Hal inilah yang membedakan manusia dengan makhluk lain, yaitu kemampuannya dalam menggunakan simbol (animal symbolicum).

Komunikasi dirumuskan sebagai suatu proses penyampaian pesan/informasi diantara beberapa orang. Karenanya komunikasi melibatkan seorang pengirim, pesan/informasi saluran dan penerima pesan yang mungkin juga memberikan umpan balik kepada pengirim untuk menyatakan bahwa pesan telah diterima. Komunikasi adalah suatu yang sangat penting dalam kehidupan manusia karena manusia adalah makhluk sosial yang saling membutuhkan satu sama lain. Dalam berkomunikasi seseorang harus memiliki dasar sebagai berikut; niat, minat, pandangan, lekat, libat. Dalam proses komunikasi kita juga harus ingat bahwa ada hambatan yaitu baik dari pengirim, saluran, penerima dan umpan balik serta hambatan fisik dan psikologis.

Tujuan komunikasi adalah berhubungan dan mengajak dengan orang lain untuk mengerti apa yang kita sampaikan dalam mencapai tujuan. Keterampilan berkomunikasi diperlukan dalam bekerja sama dengan orang lain. Ada dua jenis komunikasi, yaitu verbal dan non verbal, komunikasi verbal meliputi kata-kata yang diucapkan atau tertulis, sedangkan komunikasi non verbal meliputi bahasa tubuh. Menurut bentuk komunikasi, ada yang disebut komunikasi satu arah dan komunikasi dua arah. Komunikasi satu arah berarti sebuah pesan dikirim dari pengirim ke penerima tanpa ada umpan balik. Komunikasi dua arah terjadi bila pengiriman pesan dilakukan dan mendapatkan umpan balik. Komunikasi berdasarkan besarnya sasaran terdiri dari komunikasi massa, komunikasi kelompok, dan komunikasi perorangan.

Dalam penggunaaan komunikasi massa sebagai alat dalam berkomunikasi sering Dalam menerima informasi media massa atau yang lebih cenderung pada media sosial masa kini, masyarakat sangat mudah percaya dan mudah dipengaruhi tentang informasi yang telah menyebar. Pikiran manusia yang bebas seakan-akan terarah dalam satu masalah yang belum tentu kebenaran. Kebebasan dalam berfikir dan menerima informasi, masyarakat seakan-akan hanya mengambil kesimpulan dan persepsi dari apa yang sudah di sediakan media. Kebebasan merupakan salah satu aspek dalam masyarakat untuk mengembangkan potensi atau informasi yang mereka terima. Dalam bahasa agama, kebebasan adalah fitrahyang sejak lahir menjadi 
karakteristik potensial yang dapat berkembang, dan untuk itu Allah meletakan kebebasan pada diri setiap manusia sebagai tanda eksistensinya.

Jika ditinjau dalam segi fenomenologi, banyak fenomenolog yang beranggapan bahwa sebuah kebenaran tidak hanya bisa dinilai dari berita dan cerita yang ada, namun kehadiran diri untuk menilai sebuah kejadian itu benar atau salah adalah hal yang penting. Salah satu tokoh fenomenolog yang ternama seperti Maurice Merleau Ponty, atau yang biasa dipanggil Ponty ini berasal dari kewarganegaraan Perancis. Dia bicara banyak mengenai pengetahuan dan fenomenologi. Dengan memasukan reduksi dalam fenomenologinya, Ponty berpendapat bahwa pengetahuan akan yang konkrit diperoleh dengan pengalaman hidup secara langsung. Reduksi yang bermaksud mengembalikan semuanya pada pengalaman, membuat Ponty mengutamakan pengalaman pada setiap kejadianrealita dalam kesehariannya. ${ }^{18}$

Menurut Ponty, realitas objektif yang diolah oleh ilmu pengetahuan menjadi sesuatu yang benar adalah yang berasal dari pengalaman manusia setiap harinya. Sebuah pengetahuan tidak dapat di terima dengan benar tanpa adanya pengalaman prailmiah yang manusia peroleh secara langsung. Karena setiap kejadian yang diterima oleh manusia merupakan sesuatu yang terbatas, dan peran indra sendirilah yang akan mengembangkan persepsi manusia pada setiap pejadian yang nyata. ${ }^{19}$

Mendapat informasi lewat media saat ini mulai banyak mengambil perhatian masyarakat dalam mendapatkan informasi tanpa mengetahui kebenaran yang sesungguhnya dalam sebuah fenomena. Pengaruh media masa masa saat ini sangatpesat pengaruhnya di kalangan masyarakat. Erich Feldmann dalam Neue Studen Zur Der Massen Medien membedakan antara beberapa pengaruh media yang meliputi beberapa bidang seperti, emosi, kehidupan jiwa, pembentukan kepribadian sesuai dengan rangsangan yang diterima. Media massa yang berperan sebagai penyebar kabar untuk di konsumsi massa, memiliki peran sebagai penghubung suatu kejadian dengan pengetahuan masyarakat untuk menerimanya. ${ }^{20}$

Menurut Maurice Melelau Ponty, manusia ialah makhluk berakal yang memiliki pengembangan dalam menerima suatu informasi dan bisa menciptakan persepsi sendiri berdasarkan fakta yang mereka lihat secara langsung. Manusia bisa

\footnotetext{
${ }^{18}$ K. Bertens, Filsafat Barat Kontemporer, Jilid II, (Jakarta: PT Gramedia Pustaka Utama, 2013),130

19 Ibid,131

${ }^{20}$ Astrid S. Susanto, Filsafat Komunikasi, (Bandung: Binacipta, 1976), 48-49
} 
mengetahui sesuatu hanya melalui hubungan diri pribadi secara langsung bersentuhan dengan sesuatu yang lain seperti sebuah kejadian atau fenomena. Sebagai manusia, kita pasti memiliki gambaran pribadi mengenai apa yang kita lihat dan mempengaruhi objek itu sendiri, begitupun sebaliknya, bahwa kita juga bisa mempengaruhi pengetahuan lingkungan sekitar kita dengan menciptakan persepsi kita sendiri hingga akhirnya kita membaginya dengan orang lain hingga menjadi luas. ${ }^{21}$ Jadi jika kita hubungkan dengan komunikasi modern, manusia saat ini tidak serta merta menerima mentah-mentah informasi yang dia dapat, ia bisa saja setuju dengan men-share atau me-like, tapi ia juga tidak setuju dengan memblokir, atau keduanya dengan mengomentari informasi tersebut berdasarkan pengalaman dan pengetahuannya.

Terkait respon manusia terhadap informasi dalam komunikasi modern tersebut, manusia perlu mempelajari atau mengkaji mengenai objek informasi melalui filsafat ilmu. Filsafat Ilmu merupakan cabang dari ilmu filsafat atau bagian dari epistemologi (filsafat pengetahuan) yang secara spesifik mengkaji hakikat ilmu (pengetahuan ilmiah). Ilmu merupakan cabang ilmu pengetahuan yang mempunyai ciri-ciri tertentu. Secara metodologis, meskipun ilmu tidak membedakan antara ilmuilmu alam dengan sosial namun karena terdapat permasalah-permasalahan teknis yang khas, maka filsafat ilmu itu sering dibedakan dengan "filsafat ilmu alam" dan "filsafat ilmu sosial". Filsafat ilmu merupakan telaah secara filsafat yang ingin menjawab beberapa pertanyaan mengenai hakekat ilmu seperti :

1) Obyek mana yang ditelaah ilmu? Wujud hakiki obyek? Hubungan obyek dengan tangkapan manusia (berfikir, merasa, mengindera (yang membuahkan pengetahuan);

2) Bagaimana proses yang memungkinkan ditimba pengetahuan yang berupa ilmu? Bagaimana prosedurnya ? hal-hal apa yang harus diperhatikan agar kita mendapat pengetahuan yang benar, Apa yang disebut kebenaran itu sendiri? Apa kriterianya? Cara dan teknik sarana yang membantu kita mendapat pengetahuan yang berupa ilmu;

3) Untuk apa pengetahuan yang berupa ilmu itu dipergunakan? Bagaimana kaitan antara cara penggunaan tersebut dengan kaidah-kaidah moral? Bagaimana

${ }^{21}$ Morissan, Teori Komunikasi, . 42 
penentuan obyek yang ditelaah berdasarkan pilihan-pilihan moral? Bagaimana kaitan antara teknik prosedural yang merupakan operasinal metode ilmiah dengan norma-norma moral/ profesional. ${ }^{22}$

Objek penelitian filsafat luas sekali meliputi objek material dan penelitian yang mendalam disebut dengan objek formal. Secara garis besar filsafat memiliki 3 (tiga) cabang besar, yaitu, teori pengetahuan, teori hakikat dan teori nilai. Dengan demikian filsafat Ilmu merupakan cabang ilmu filsafat yang mengkaji ilmu dari sisi filsafat untuk memberi jawaban terhadap sejumlah pertanyaan yang mencakup : 23

a. Teori pengetahuan membicarakan cara memperoleh pengetahuan disebut dengan, epistemologi;

b. Teori hakikat membicarakan pengetahuan itu sendiri disebut, ontologi;

c. Teori nilai membicarakan guna pengetahuan, disebut dengan aksiologi.

Perbincangan mengenai filsafat ilmu baik secara kualitatif maupun kuantitatif berkembang pesat dan mendalam sejak tahun 1960 -an sampai akhir abad $20 .{ }^{24}$ Francis Bacon dengan metode induksi yang ditampilkannya pada abad ke-sembilan belas dapat dikatakan sebagai peletak dasar filsafat ilmu dalam khasanah bidang filsafat secara umum. Sebagian ahli filsafat berpandangan bahwa perhatian yang besar terhadap peran dan fungsi filsafat ilmu mulai menemuka tatkala ilmu pengetahuan dan teknologi mengalami kemajuan yang sangat pesat. Dalam hal ini ada semacam kekhawatiran di kalangan ilmuan, dan filosof, termasuk juga kalangan Agamawan, bahwa kemajuan ilmu pengetahuan dapat mengancam eksistensi umat manusia bahkan agama itu sendiri. 25

Jika dianalisis secara ontologi, maka perkembangan ilmu dalam temuan inovasi baru, berakibat kepada perubahan cara pandang tentang ilmu pengetahuan. Kondisi ini memiliki peran penting membentuk peradaban dan kebudayaan manusia. Namun semakin maju pengetahuan, semakin meningkat hasrat keinginan manusia yang sampai menghalalkan segala cara, serakah dan tamak untuk mencapai tujuannya.

\footnotetext{
${ }^{22}$ Jujun S. Suriasumantri, Filsafat Ilmu Sebuah Pengantar Populer, (Jakarta; Pustaka Sinar Harapan, 2005), 33-34.

${ }^{23}$ Ahmad Tafsir, Filsafat Umum: Akal dan Hati Sejak Thales sampai Capra, (Bandung; Rosda, 2007), 22-23., bandingkan dengan Jujun S Suriasumantri, Filsafat Ilmu Sebuah Pengantar Populer, (Jakarta; Pustaka Sinar Harapan, 2005),35.

${ }^{24}$ Noeng Muhajir, Filsafat ilmu Kualitatif dan Kuantitatif untuk Pengembangan Ilmu dan Penelitian, (Yogyakarta; Rake Sarasin,2006),1. Lihat juga The Liang Gie, Pengantar Filsafat Ilmu, (Yogyakarta; Liberty, 2007), 65.

${ }^{25}$ Andi Hakim Nasution, Pengantar Ke Filsafat Sains, (Jakarta; Litera AntarNusa, 2008),14-15.
} 
Akibatnya ilmu pengetahuan dan hasilnya tidak manusiawi lagi, bahkan cenderung memperbudak manusia sendiri yang telah merencanakan dan menghasilkannya suatu temuan tersebut.

Kecenderungan yang merugikan bahkan menimbulkan dampak buruk dan mengancam keamanan dan kehidupan manusia, dewasa ini dapat dicontohkan dalam bidang komunikasi banyak kebohongan publik marak saat ini sehingga bencana moralitas dan peradaban yang efeknya jauh lebih merusak sistemik, dan mematikan ketimbang bencana alam. Efek kerusakannya memiliki mata rantai yang sangat panjang. Selain itu, upaya pemulihannya membutuhkan waktu cukuplama.

Fenomena kebohongan publik tengah menghiasi ruang-ruang publik kita. Fenomena tersebut tidak bisa dilepaskan dari dahsyatnya gelombang media sosial yang menggantikan pola komunikasi konvensional di ruang publik. Sayangnya, gelombang media sosial itu tidak diantisipasi dengan baik melalui pemberdayaan akal sehat dan pertahanan literasi yang memadai.

Saat yang sama, masyarakat mengalami gejala miopia; tidak bisa mengenali mana yang fakta dan mana yang hoax. Efek destruksi hoax kian membentuk mata rantai roda produksi ekonomi-politik yang menjanjikan keuntungan melimpah. Eksistensi mereka tak terbendung akibat struktur kesempatan yang dilahirkan industri media sosial.

Hoax tengah menjadi komoditas. Ada banyak orang hidup dari hoax. Informasi palsu dan berita bohong hanyalah gugusan ide yang difabrikasi secara kreatif dan berdaya jual tinggi. Bagi orang orang semacam itu hoax bisa "memberkahi". Tanpa hoax mereka akan tenggelamkan dan mati. Karena itu mereka pasti akan menempuh segala cara untuk tetap hidup dari dan menghidupkan, hoax. Bahkan dalam derajat tertentu hoax telah menjelma menjadi ideologi baru yang dipersepsi sebagai “ jalan suci" untuk menggapai kemenangan dan kejayaan, terlebih kemenangan yang dilegitimasi oleh normavitas keagamaan. Maka, jadilah "berita bohong” sebagai sebuah kebenaran yang dianggap boleh dilakukan dalam sebuah kontestasi politik. Padahal, tidak ada yang sakral dari sebuah kebohongan bahkan dalam Al-Quran, Allah secara tegas melarang tindakan hoax, yakni membuat berita palsu atau menyebarkan berita bohong dalam firman-Nya: 


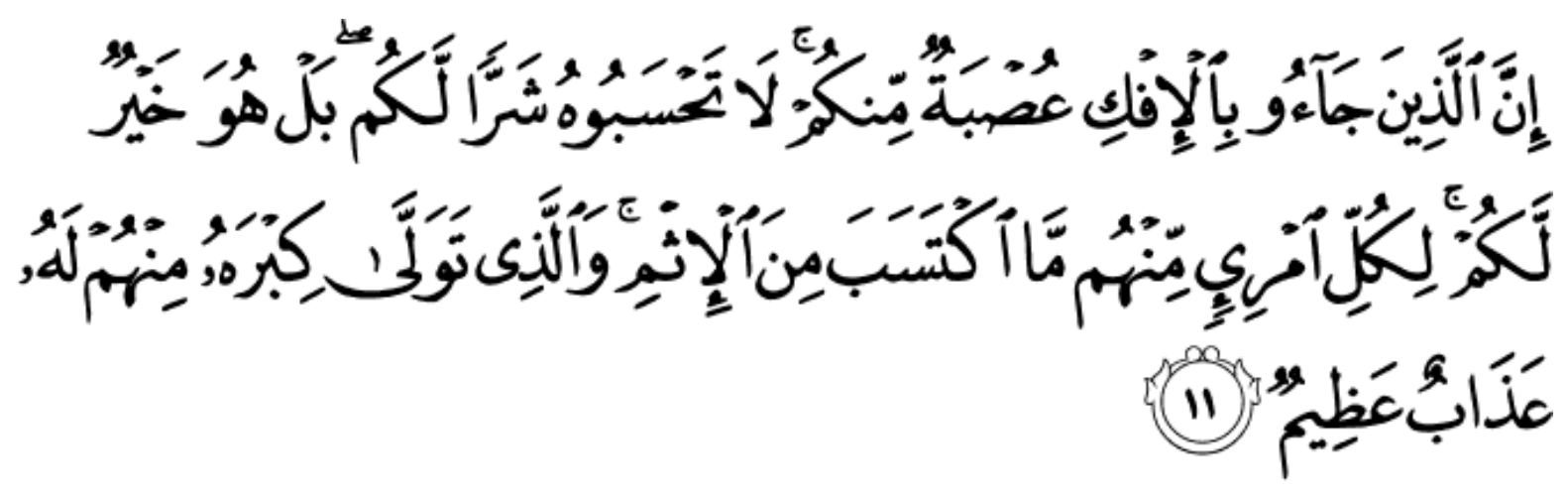

Artinya: "Sesungguhnya orang-orang yang membawa berita bohong itu adalah dari golongan kamu juga. Janganlah kamu kira bahwa berita bohong itu buruk bagi kamu bahkan ia adalah baik bagi kamu. Tiap-tiap seseorang dari mereka mendapat balasan dari dosa yang dikerjakannya. Dan siapa di antara ${ }^{26}$ mereka yang mengambil bahagian yang terbesar dalam penyiaran berita bohong itu baginya azab yang besar." (QS. An-Nur:11) ${ }^{27}$

Selain Allah melarang membuat berita hoax, Allah juga meminta kita untuk menelaah kebenaran dan tetap berprasangka baik terhadap berita tersebut melalu firman-Nya:

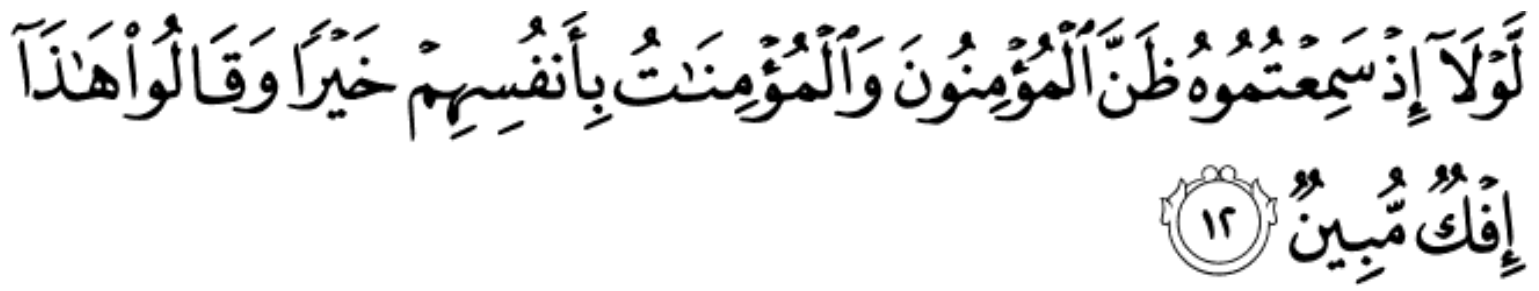

Artinya: "Mengapa di waktu kamu mendengar berita bohong itu orang-orang mukminin dan mukminat tidak bersangka baik terhadap diri mereka sendiri, dan (mengapa tidak) berkata: "Ini adalah suatu berita bohong yang nyata."(QS An-Nur:12)

Dari ayat tersebut dapat kita simpulkan bahwa saat ada berita bohong atau provokasi yang tersebar dan viral di masyarakat, kita tetap diminta untuk berbaik sangka dan menghilangkan prasangka buruk. Hal inilah yang kurang disadari oleh manusia modern yang lebih banyak terprovakasi tanpa menelaah terlebih dahulu.

Di sisi lainnya, ilmu pengetahuan dan teknologi baik langsung maupun tidak langsung berkaitan dengan struktur sosial dan politik yang berhubungan erat dengan jutaan manusia yang kelaparan, kemiskinan, pengangguran, meninggal karena penyakit dan peperangan serta berbagai jenis ketimpangan, yang justru menjadi pandangan yang mencolok di tengah keyakinan manusia akan keampuhan ilmu pengetahuan dan teknologi menghapus penderitaan manusia.

\footnotetext{
${ }^{26} \mathrm{Al}$-Quran dan Terjemahan, Departemen Agama

27 Ibid
} 
Kesadaran muncul dalam lingkungan ilmuan yang prihatin akan perkembangan teknik, industri, yang membahayakan masa depan kehidupan umat manusia dan bumi. Untuk itulah maka epistimologi ilmu bertugas menjawab pertanyaan mengenai bagaimana proses pengetahuan yang masih berserakan dan tidak teratur itu menjadi suatu ilmu, bagaimana prosedur dan mekanismenya, hal-hal apa yang harus diperhatikan agar mendapatkan pengetahuan yang benar, apa yang disebut kebenaran itu sendiri, bagaimana kreteria sebuah kebenaran, bagaimana cara, teknik, sarana yang dapat membantu dalam mendapatkan pengetahuan yang berupa ilmu.

Dari epistimologi tersebut, jika kita kembali ketujuan awal dari komunikasi, maka seharusnya problematika komunikasi bias ditanggulangi. Griffin memaparkan bahwa komunikasi adalah pengelolaan pesan dengan tujuan untuk menciptakan makna. Jika kita lihat definisi ini agak bersifat luas, namun tepat jika kita akan menentukan apa yang terjadi dalam setiap tahap komunikasi, yaitu berusaha mengetahui untuk apakah suatu proses komunikasi akan berhasil atau gagal baik dalam konteks komunikasi antar pribadi maupun komunikasi dalam suatu kelompok. Dengan kata lain, jika komunikasi dianggap sebagai tujuan, baik membujuk, menginformasikan, atau menghibur maka kita berkomunikasi dengan niat, dan kita dapat mencapai tujuan kita hanya dengan berinteraksi dengan seseorang. ${ }^{28} \mathrm{Jika}$ kita tilik definisi Griffin tersebut tentu apapun masanya, entah klasik maupun modern, komunikasi seharusnya bertujuan untuk menciptakan suatu makna yang positif kepada masyarakat. Dengan kembali definisi tersebut, tentunya salah satu problem komunikasi (hoax misalnya) tentu bisa ditanggulangi dengan baik.

Tiang penyangga filsafat ilmu yang ketiga adalah aksiologi ilmu. Ilmu adalah sesuatu yang paling penting bagi manusia. Hal ini karena melalui ilmu semua keperluan dan kebutuhan manusia dapat terpenuhi secara lebih cepat dan lebih mudah. Adanya peradaban manusia tidak dapat dipungkiri sangat berhutang pada ilmu. Ilmu telah banyak mengubah wajah dunia seperti, memberantas penyakit, kelaparan, kemiskinan dan berbagai wajah kehidupan yang sulit lainnya. Dengan kemajuan ilmu juga, manusia bisa merasakan kemudahan lainnya seperti transportasi, pemukiman, pendidikan, informasi dan komunikasi, dan lain sebagainya.

\footnotetext{
${ }^{28}$ Dendy Suseno Adhiarso, Prahastiwi Utari dan Yulius Slamet, Pemberitaan Hoax di Media Online Ditinjau dari Konstruksi Berita dan Respon NetizenJurnal Ilmu Komunikasi, Volume 15, Nomor 3, September Desember 2017, halaman 217.
} 
Dengan kata lain "ilmu" merupakan sarana untuk membantu manusia dalam mencapai tujuan hidupnya. Namun, jika suatu ilmu yang pada awalnya diciptakan tujuan mulia misalnya, adanya diciptakan gawai memudahkan kerja manusia, sayangnya justru peruntukan gawai terkadang menimbulkan malapetaka menghancurkan dan membunuh antara sesama manusia itu sendiri. Di sinilah ilmu harus diletakkan secara proposional dan memihak pada nilai-nilai kebaikan dan kemanusiaan. Sebab, jika ilmu tidak berpihak kepada nilai-nilai, maka yang terjadi adalah bencana dan malapetaka.

Setiap ilmu pengetahuan menghasilkan teknologi yang kemudian diterapkan pada masyarakat. Proses ilmu pengetahuan menjadi sebuah teknologi tujuannya adalah dimanfaatkan bagi kemashalatan manusia. Dalam konteks seperti ini, seorang ilmuan yang menemukan suatu teknologi dihadapkan pada kepentingan-kepentingan pribadi bersifat komersial ataukah kepentingan masyarakat yang memiliki fungsi sosial. Persoalan etika keilmuan akan membawa kepada masalah bebas nilai. Untuk itulah tanggungjawab seorang ilmuan haruslah dituntut dan ditempatkan pada posisi yang tepat, tanggung jawab akademis, dan tanggung jawab moral.

Selanjutnya dikatakan Muhammad Erwin, manfaat mempelajari ilmu filsafat ilmu diantaranya:

1. Menghindari timbulnya pandangan bahwa pengertian sudah menjamin perbuatan, namun pengertian serba sedikit tantangan ilmu filsafat dapat digunakan sebagai pedoman kenyataan kehidupan sehari-hari, baik sebagai individu maupun anggota masyarakat.

2. Sebagai pandangan hidup yang mantap yang akan menentukan kriteria baik buruknya tingkah laku kita yang telah kita pilih atas dasar keputusan batin kita sendiri, manusia telah memilki kebebasan dan kepribadian sendiri

3. Mengurangi dan menghindari gejala negatif dalam hidup (negative thinking) agar hidup lebih terarah dan tepat.

4. memiliki tingkah laku hidup bertujuan, yang didasarkan dan ditentukan oleh filsafat hidupnya agar tingkah lakunya lebih bernilai. ${ }^{29}$

${ }^{29}$ Dalam Mukhtar Latif . Filsafat Ilmu, Orientasi ke Arah Pemahaman, (Jakarta; prenadamedia grup, 2014). 41 
Setya Widyawati dalam jurnalnya Filsafat Ilmu sebagai Landasan Pengembangan Ilmu Pendidikan menuliskan bahwa dengan mempelajari filsafat ilmu maka memberi beberapa manfaat, diantaranya:

a. Melatih berfikir radikal tentang hakekat ilmu

b. Melatih berfikir reflektif di dalam lingkup ilmu

c. Menghindarkan diri dari memutlakkan kebenaran ilmiah, dan menganggap bahwa ilmu sebagai satu-satunya cara memperoleh kebenaran

d. Menghindarkan diri dari egoisme ilmiah, yakni tidak menghargai sudut pandang lain di luar bidang ilmunya. ${ }^{30}$

Dari manfaat itu, bisa kita simpulkan bahwasanya manusia bisa terhindar dari informasi palsu dan provokatif jika mampu berpikir secara kritis dengan menyelidiki kebenaran informasi (ilmu pengetahuan) yang diperoleh.

Dengan demikian eksistensi ilmu mestinya tidak dipandang sebagai sesuatu yang sudah final, dia perlu dikritisi, dikaji, bukan untuk melemahkannya tapi untuk memposisikan secara tepat dalam batas wilayahnya. Hal inipun dapat membantu terhindar dari memutlakan ilmu dan menganggap ilmu dan kebenaran ilmiah sebagai satu-satunya kebenaran, disamping perlu terus diupayakan untuk melihat ilmu secara integral bergandengan dengan dimensi dan bidang lain yang hidup dan berkembang dalam membentuk peradaban manusia. Dalam hubungan ini filsafat ilmu akan membukakan wawasan tentang bagaimana sebenarnya substansi ilmu itu. Hal ini karena filsafat ilmu merupakan pengkajian lanjutan dan refleksi atas ilmu dengan demikian ia merupakan syarat mutlak untuk menentang bahaya yang menjurus kepada keadaan cerai berainya ilmu. Disamping itu untuk menjaga keseimbangan pertumbuhan ilmu-ilmu yang ada, melalui pemahaman tentang asas-asas, latar belakang serta hubungan yang dimiliki/dilaksanakan oleh suatu kegiatan ilmiah.

\section{KESIMPULAN}

Ilmu membatasi penjelajahannya pada pengalaman manusia, karenanya ilmu memulai pada penjelajahan pada pengalaman manusia dan berhenti pada pengalaman manusia, dan itu lah batas ilmu. Namun keilmuan harus tetap didasari dengan dasar keagamaan yang bisa membuat seseorang lebih bijaksana dalam menerapkan keilmuannya.

\footnotetext{
${ }^{30}$ Setya Widyawati Filsafat Ilmu Sebagai Landasan Pengembangan Ilmu Pendidikan, GELAR Jurnal seni dan budaya Volume 11 No. 1 Juli 2013, (Surakarta: Institut ISI Surakarta, 2013), 94.
} 
Dari pembahasan tersebut dapat kita simpulkan bahwa filsafat ilmu memilki kontribusi terhadap dunia komunikasi modern. Meski banyak oknum yang menyalahgunakan komunikasi namun bisa kita menanggulanginya melalui ontologi, epistimologi, dan aksiologi. Melalui filsafat ilmu, ada beberapa cara yang bisa ditempuh dalam mengatasi problematika komunikasi modern:

1. Untuk tetap membatasi penyebaran informasi dengan tetap berpegang pada dasar-dasar agama.

2. Para stakeholder dalam bidang komunikasi modern perlu untuk menelaah lagi informasi yang disebarluaskan sehingga masyarakat tidak salah dalam menerima infomasi (misscommunication) sehingga bisa meminalisir dampak buruk yang bisa timbul.

3. Masyarakat juga perlu mempelajari filsafat ilmu agar tidak mudah terprovokasi dan salah tafsir atas informasi yang disebarkan dalam komunikasi modern.

Kedua pihak (penyebar dan penerima berita) untuk tetap saling mengawasi dan mengingatkan untuk menghindari dampak negatif dari informasi yang disebarkan.

\section{DAFTAR PUSTAKA}

Al-Quran dan Terjemahan, Departemen Agama

Burhanuddin, Nunu.2018.FilsafatIlmu, Jakarta: Prenadamedia,

Cassirer, Ernst. 1987.Manusia dan Kebudayaan Sebuah Esei Tentang Manusia, ter.Alois A Nugroho, Gramedia: Jakarta

Ghulsyani, Mahdi, 1994 Filsafat-Sains Menurut Al-Quran, ter. Agus Effendi, Bandung; Mizan

Geraudy, Roger. 1982 Janji-Janji Islam, terj. H.M.Rasyidi. Bulan Bintang. Jakarta

Hamid Fahmi Zarkasy, Seminar Pandangan Hidup dan Epistemologi Islam: Studi Kasus Sains Islam, “Pandangan Hidup sebagai Asas Epistemologi Islam”, 2006.

Hatta, Mohammad.1964.Pengantar ke Jalan Ilmu dan Pengetahuan. PT Pembangunan: Jakarta

Https://apjii.or.id/survei2017 diunduh tanggal 27 Oktober 2018

Http://cnnindonesia.com/teknologi/20161230125808-185-183096/asal-mulasitus-hoax-berkembang-di-indonesia/ diunduh tanggal 27 Oktober 2018 
Https://kominfo.go.id/index.php/content/detail/4286/Pengguna+Internet+Indone sia+Nomor+Enam+Dunia/0/sorotan_media diunduh tanggal 27 Oktober 2018.

Https://kominfo.go.id/content/detail/8629/asal-mula-situs-hoax-berkembang-diindonesia/0/sorotan_media diunduh tanggal 27 Oktober 2018

Http://pusdiklat-dewandakwah.com/ diunduh tanggal 27 Oktober 2018

Keraf A.Sonny \& Dua, Mikhael.2001 Ilmu Pengetahuan, Sebuah Tinjauan Filosofis. Kanisius: Yogyakarta.

Kirom, Syahrul.2011.Filsafat Ilmu dan Arah Pengembangan Pancasila: Relevansinya dalam Mengatasi Persoalan Kebangsaan. Jurnal Filsafat Vol.21, Nomor 2, Agustus 2011. UGM: Yogyakarta

Latif, Mukhtar. 2014.Filsafat Ilmu, Orientasi ke Arah Pemahaman.Prenadamedia Grup: Jakarta

Muhaimin.2005. Studi Islam dalam ragam dimensi dan pendekatan. Prenadamedia Group: Jakarta

Setya Widyawati.2013. Filsafat Ilmu sebagai Landasan Pengembangan Ilmu Pendidikan, GELAR Jurnal seni dan budaya Volume 11 No. 1 Juli 2013, Institut ISI Surakarta: Surakarta

Suseno,Dendy.dkk. 2017, Pemberitaan Hoax di Media Online Ditinjau dari Konstruksi Berita dan Respon Netizen. Jurnal Ilmu Komunikasi, Volume 15, Nomor 3, September - Desember 2017

Van Peursen, C.A. 1985. Susunan Ilmu Pengetahuan Sebuah: Pengantar FilsafatIlmu, ter. J. Drost, Gramedia: Jakarta 